Vol. 59: e16150684, January-December 2016 http://dx.doi.org/10.1590/1678-4324-2016150684 ISSN 1678-4324 Online Edition
BRAZILIAN ARCHIVES OF

BIOLOGY AND TECHNOLOGY

AN INTERNATIONAL JOURNAL

\title{
Sustainable Management of Keratin Waste Biomass: Applications and Future Perspectives
}

\author{
Swati Sharma ${ }^{1}$; Arun Gupta ${ }^{\text {* }}$ \\ ${ }^{1}$ University Malaysia Pahang, chemical and natural resource engineering \\ kuantan, Pahang, Malaysia
}

\begin{abstract}
Keratin is a durable, fibrous protein which is mainly present in higher vertebrates (mammals, birds and reptiles) and humans epithelial cells. Food industry especially the meat market, slaughter house and wool industry produces million of tons of keratin containing biomass. These industries are constantly growing and the major producers include USA, Brazil and China, account for more than 40 million tons per year. These proteins constitute keratin by-products have from 15 to $18 \%$ nitrogen, 2-5\% sulphur, 3.20\% mineral elements and $1.27 \%$ fat and $90 \%$ of proteins. The organic waste rich in keratin can be utilized as a natural source using chemical and mechanical methods. The natural keratin obtained by biomass does not contain any harmful chemical and can be used directly to produce variety of cosmetics, creams, shampoos, hair conditioners and biomedical products. The natural protein is more compatible to use or apply on human skin and hairs. The monomeric units of natural keratin can penetrate in the skin and hair cuticle and able to nourish the skin without any side effects. In the present review various strategies for the purification and separation of keratin from the organic waste have been described and use of natural keratin in cosmetics and pharmaceutical industry has also been explored.
\end{abstract}

Key words: Keratin, purification, cosmetics, cuticle, coatings, hygroscopic, industrial applications

\footnotetext{
*Author for correspondence: arungupta10@gmail.com
} 


\section{INTRODUCTION}

The keratin is one of the most abundant proteins found in the body of mammals, birds and reptiles. It is a structural component of wool, nail, horn and feathers and provides strength to body (Reichl et al. 2011).It is mainly present in epithelial cells in higher vertebrates (Teresa and Justyna 2011). With developing urbanization, food industries especially the meat market, slaughter house and wool industry produces millions of tons of keratin containing biomass. The major producers include USA, Brazil and China, account for more than 40 million tons per year. These proteins constitute keratin by-products have from $2-5 \%$ sulphur, 15 to $18 \%$ nitrogen, $3.20 \%$ mineral elements and $1.27 \%$ fat and $90 \%$ of proteins ( Kunert 2000; Sangali and Brandelli 2000; Gessesse et al. 2003). Globally chicken feathers are the most common waste product of keratin, with high amounts produced in poultry slaughterhouses. These organic waste can be utilized as a natural source to extract the keratin and use it in commercial applications. Keratins are the cysteine rich proteins associated with intermediate filaments (IFs) which are cytoskeleton element with diameter of 8-10 nm (Arai et al. 1983; Khosa et al. 2013). It is mainly found in two forms $\alpha$ and $\beta$-keratin. $\alpha$ keratins are abundantly found in the soft tissues such as sheep wool, skin and hair. These are rich in cysteine and contained less amount of hydroxyproline and proline amino acids. However $\beta$-keratins are present in hard tissue protein of bird feathers, fish scales, nails and others. They are rich in alanine and glycine, poor in cysteine, hydroxyproline and proline (Gupta et al. 2012). Chemically keratins are highly stable and insoluble in most of organic solvents. The presence of cysteine in ample amount made keratin susceptible for hydrolytic and oxidation reactions ( Schrooyen et al. 2001; Barone and Schmidt 2006; Endo et al. 2008). Now days a large amount of keratin by-products are wasted which is potential threat to the environment (Cavello et al. 2012; Park et al. 2013). Keratin waste is classified in three groups in regulation (EC) 1774/2002 of the European Parliament and Council of 3rd October 2002 set down health rules concerning animal by-products not anticipated for human utilization. It is unsuitable for ingestion but does not transmit diseases to humans or animals (Teresa and Justyna 2011). In the form of solid biomass keratin is less prone to enzymatic hydrolysis due to high cross-linking by disulfide bonds, hydrophobic interactions and hydrogen bonding ( Teresa and Justyna 2011). In recent years, several attempts were made for the extraction of keratin using chemical, mechanical and enzymatic methods ( Jeong et al. 2010; Korol 2012; Chaudhari et al. 2013; Fang et al. 2013). One of the potential application of purified keratin is to generate biomaterials in tissue repair and regeneration (Alsarra 2009; Ramshaw et al. 2009; Natarajan et al. 2012; Ramadass et al. 2013). Chemical composition, structure and occurrence of keratins: Keratin is the major component of hair, wool, nails, hooves, claws, scales, horn, beaks and feathers. These are least affected by chemical and physical environmental factors (Teresa and Justyna 2011). Chemical structure of keratin showed $\alpha$-helix, $\beta$-helix or $\beta$-pleated sheet (Fraser et al. 1972; Lee and Baden 1975). The high cysteine content is peculiar characteristic of keratin which distinguish it from other structural proteins like collagen and elastin. Major amino acids present in keratin are cysteine, glycine, proline, serine and a low content of lysine, histidine and methionine is also present (Fraser et al. 1972; Jones 2001; Fraser and Parry 2003). In another study beside $\alpha, \beta$ a third type of amorphous protein, $\gamma$-keratin was extracted which is non-structural and associated with $\alpha$ and $\beta$ sheets (Jones 2001; Fraser et al. 1972). The ratio of sulphur content also play important role in physical properties of keratin. Some researchers classified keratin as soft and hard forms based upon sulphur content (Rizvi and Khan 2008; Zoccola et al. 2009). Soft keratin has lower cystine content, week cross linking and smaller resistant to other chemicals found in the hair core and outer layer of epidermis (Fraser et al. 1972). Hard keratin found in mammalian epidermal appendages, such as horns, hairs, nails, and in avian or reptilian tissues. In recent years, equine hoof (Douglas et al. 1996) bovine hoof, wool (Feughelman and Robinson 1971) and especially the sheep horn (Tombolato et al. 2010) are the attractive sources for keratin extraction. In $\alpha$-keratin individual polypeptide chains in the $\alpha$-helix stabilized by hydrogen bonds and disulfide bridges were formed by cysteine residues 
between adjacent chains (Marchisio 2000; Jones 2001).

\section{Sources of keratin biomass}

Keratin biomass is derived from living organisms or from their body parts after death. The major livestock's of keratin includes goatskins, sheepskins, cattle hides and buffalo hides as shown in Fig 1. Skin and its appendages such as nails, hair, feathers, wool, hooves, scales and stratum corneum are the richest source of keratin (Kim 2007). It can be extracted from animal horns and hooves wool and human hairs (Fig. 1). Several million tonnes of feathers are produced annually. Hairs are the by-product from tanneries during haircut process and 5\% of dry hair weight generally recovered from raw material (Cranston et al. 1986). Food industry produces million tons of keratin biomass. About $80 \%$ of human hair is formed of keratin only (Kaplin et al. 1982; Wagner and Joekes 2005). It provides strength, flexibility, durability and functionality to the hair in the form of different conformations (Velasco et al. 2009).

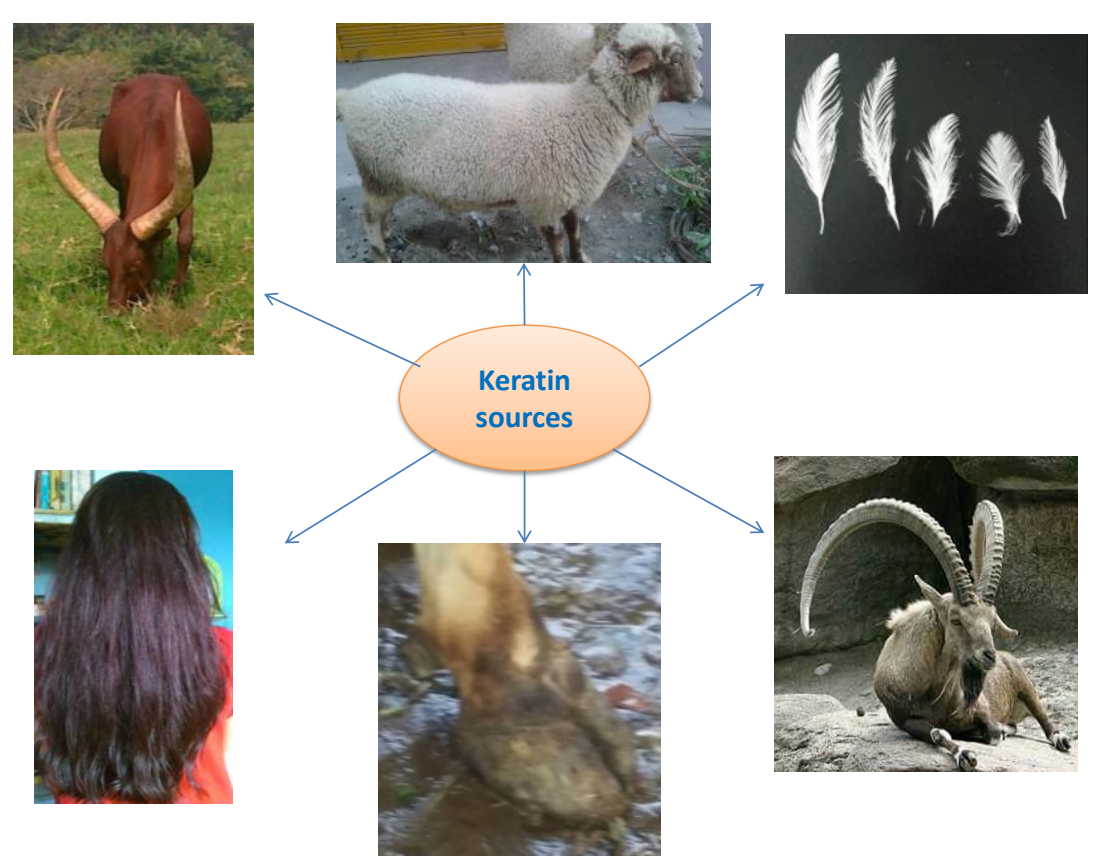

Figure1- Major sources of keratin biomass

\section{Impact on environmental pollution}

The need of chicken, wool, fish, birds and reptiles in the food and textile industry is recognizable but the proper disposal of waste products is also essential. The continuous use of these sources for human needs and generation of loads of waste leads to the accumulation of waste in ecosystem. The use of higher concentrations of poultry extended to environmental problems at regional to global scales (Gerber et al. 2007). Landscape degradation and local disturbance like odor, flies and rodents are the main problems near the poultry farms. This is also causing water and soil pollution and adversely affect the life of people living in the nearby localities
(Gerber et al. 2007). Literature survey revealed that more than 4 billion pounds of feathers produced in United States each year are disposed in the landfills which directs to the environmental pollution and leading to the deterioration of a valuable resource (Huda and Yang 2008). The second major environmental issue is created by the slaughterhouses. The contaminated water generates the problems of eutrophication, decreased species diversity and acidification of soils because of deposition of nitrogen. High concentration of metal ions and nitrate leaching leads to the pollution of soil and ground water respectively. Also sheep wool which is the purest form of keratin in all the biomass is unsuitable for processing in the 
textile industries. The traditional strategies used for the disposal of chicken feather are not only expensive but difficult and not so effective too. These are often burned in incineration, buried in landfills or recycled into low quality feeds for the animals. However, these disposal methods are restricted because huge emission of greenhouse gases which poses great danger to environment (Verheyen et al. 1996).

\section{Physico-chemical methods of conversion of waste biomass methods of extraction of keratin}

Due to the property of biodegradability, mechanical strength, biocompatibility and natural profusion, expansion of keratin-based stuff has become the prospective for transforming the bio-based green materials in industries (Balaji et al. 2012; Poole et al. 2009). From environmental and economic point of views, it is quite desirable to automate profitable and effectual manner to use these kind of sources in green chemistry (Wang and Cao 2012). During last decades, study has attentive on the extraction, purification, characterization, and applications of keratin protein from wool fibers, hair, and nails (Rouse and Van Dyke 2010). However, most abundant keratinous material are chicken feathers $(\mathrm{CF})$ in the nature (Onifade et al. 1998).

\section{Chicken feather as a source of keratin}

Feather keratin is a potential source of inexpensive, ecofriendly and commercial biomaterial (Poole et al. 2009; Shi et al. 2014). Chicken meat produces approximately 5 million tones feathers per year by meat processing as a waste stream. The value of collected feather is very less in poultry industry. The minor consumption of feathers biomass leads to accumulation which poses an important environmental risk to the poultry farming industry and landfills. It consist of $90 \%$ of keratin and can be utilized for industrial applications (Teresa and Justyna 2011). But certain limitations in feather keratin processing like poor solubility has restricted its use and increased the cost of process (Reddy and Yang 2007). However, its solubility in water raises at high temperature, low/acidic $\mathrm{pH}$ and in presence of chemical reducing agent (i.e. $\mathrm{Na}_{2} \mathrm{SO}_{3}$ or $\mathrm{Na}_{2} \mathrm{~S}$ ). Feather keratin proteins are small and uniform in size, with a molecular weight around $10 \mathrm{kDa}$ (Arai et al. 1983; Ullah et al. 2011). Feather keratin protein consist of hydrogen bonds, hydrophobic forces and covalent interactions such as disulfide bond (Wang and Cao 2012). These constitute cystine, hydrophobic residues and $\beta$-sheet conformations (Onifade et al. 1998; Guhados et al. 2005). The presence of reactive functional groups, especially peptide backbone, disulfide (-S-S) bridges, amino ($\mathrm{NH}_{2}$ ) and carboxylic acid (-COOH), make it chemically reactive under favorable reaction conditions. During controlled reduction, disulfide cross-links are broken into free thiol $(-\mathrm{SH})$ groups with the protonation of $-\mathrm{NH}_{2}$ and other groups in keratin which creates positive charge on its surface. Thus, protonation, the keratin protein acquire positive surface charge and become pseudocationic biopolymer. It can be developed in various forms, for instance, gels, films, beads and nano/micro-particles. Undoubtedly, after modification, it finds numerous applications in green chemistry, food sciences, pharmaceutical, and cosmetic industries. There are number of methods developed to extract keratin using oxidative and reductive chemical processes. These technologies were initially applied on animal's horns and hoofs, chicken feathers and human hairs. Many researchers used Shindai method to extract the keratin from poultry feathers under reducing conditions (Schrooyen et al. 2001; Moore et al. 2006; Khosa and Ullah 2013).

\section{Bovine hoof as a source of keratin}

Bovine hoof is also an important source of keratin which can be processed by chemical and mechanical treatment. Urea based chemical treatment is common method for the extraction of keratin from hooves. Some other chemical agents like sodium dodecyl sulfate (for disruption of strong intermolecular interactions), and $\beta$-mercaptoethanol (to cleave the disulfide bonds) were also used in literature to extract the keratin in the form of aqueous solution (Yamauchi et al. 1998). Keratin is $\mathrm{pH}$ sensitive too and undergo decomposition in alkaline conditions. The optimum $\mathrm{pH}$ range employed for extraction was $6-8$. This aqueous solution obtained by chemical treatment of raw hooves can be stored at $25^{\circ} \mathrm{C}$ for one year (Srinivasan et al. 2010). A chemical hydrolytic process of extraction of keratin from hooves was 
described by (Kakkar et al. 2014). The fats can be removed from the hoofs by defatting in soxhlet's apparatus. The defatted protein can be refluxed with hexane and dichloromethane. It is followed by mixing with urea, SDS and mercaptoethanol in flask and kept at $60^{\circ} \mathrm{C}$ for $12 \mathrm{~h}$ under shaking conditions. The hydrolyzed protein samples can be centrifuged to remove the particulate matter and supernatant is dialyzed and lyophilized to powder form. The protein quantification can be done by Lowery's and Bradford assay methods.

\section{Keratin from sheep wool}

Wool is a natural protein fiber and contains pure keratin which is $95 \%$ by weight. The main morphological component of wool is composed of spindle-shaped cortical cells of low-sulfur intermediate-filament proteins (IFPs) $(40-65 \mathrm{kDa})$ with a predominantly $\alpha$ helical structure entrenched into an amorphous matrix of $\beta$-keratin sheets. The keratinassociated proteins (KAPs) are composed of high sulfur rich proteins (11-26 kDa) and the glycine-tyrosine rich proteins $(6-9 \mathrm{kDa})$ Vasconcelos et al. 2008; Zoccola et al. 2009; Cardamone 2010). The keratin protein obtained from sheep wool consist of high percentage of cystine amino acid. Because of the strong disulfide bonds this protein made it insoluble in water, organic solvents and dilute acids alkalis (Eslahi et al. 2013).

\section{Characterization methods of keratin}

Extracted keratin is evaluated and characterized by using different techniques for confirmation of proteins and amino acid composition. Presence of keratin is confirmed by biuret test and confirmation of the presence of particular amino acid can be studied by FTIR and XRD analysis (Gupta et al. 2012) In the previous studies, the vibration in the peptide bonds stretching in functional groups was described. Commonly in keratin, Amide showed $\mathrm{C}=\mathrm{O}$ stretching vibration with range of $1700-1600 \mathrm{~cm}^{-1}, \mathrm{C}-\mathrm{H}$ stretching vibration at $1520 \mathrm{~cm}^{-1}$ and $1220-1300 \mathrm{~cm}^{-1}$ shows C-N stretching ( Wojciechowska et al. 1999; Aluigi et al. 2007; Sun et al. 2009). One sharp peak of average molecular weight of extracted keratin by using gel permeation chromatography (GPC) is at 10,240 (Wang and Cao 2012). The number average molecular weight and weight average molecular weight of the extracted keratin studied by using GPC was 8829 and 9736 respectively (Ji et al. 2014). Extracted keratin from wool was also measured by using MALDI-TOF/TOF (Matrix Assisted Laser Desorption/ Ionization mass spectrometry). The size of the isolated protein homologs was estimated by using SDS-PAGE gel electrophoresis. Keratin microstructure was inspected by alkaline and reduction hydrolysis (Cardamone 2010).

\section{Industrial potential of keratin}

The earliest recognized use of keratins for medicinal applications comes from a Chinese herbalist named $\mathrm{Li}$ Shi-Zhen in the 16 th century. Over a 38-year period, Shi-Zhen wrote a collection of 800 books known as the Ben Cao Gang $M u$ that illustrate more than 11,000 therapeutic prescriptions. Among these, a substance made of ground ash from pyrolized human hair that was used to accelerate wound healing and blood clotting also known as Crinis Carbonisatus. Although the details about the discovery of the biological activity of human hair are not reported in detail, its uses for medicinal purposes are clearly documented by Zheng et al. (2005). Also, Keratin does not contain any harmful compounds and can be used directly to produce variety of cosmetics, creams, shampoos, hair conditioners and pharmaceutical products. The soluble keratin would have applications in wound healing, tissue regeneration, cell seeding, diffusion, and drug delivery (Yamini Satyawali 2013). Keratin from feathers used to made films, fibers, hydrogels, micro and nanoparticles for the purpose of food, cosmetology, medical, textile, composite, agriculture and other industries.

\section{Uses in cosmetic industry}

Keratin is hydrolyzed by acid, alkali or enzyme and keratin hydrolysate have huge applications in cosmetic industries. Keratin based cosmetics have been reported as a treatment of skin and human hair (Weigmann et al. 1990; Innoe 1992. Keratin with other natural polymers such as collagen, chitosan, silk fibroin were used as a components of the blends for cosmetic applications (Sionkowska 2015). Presence of keratin in the stratum corneum and hair cuticle helps in retaining moisture in skin by interacting with cosmetics. 
High molecular weight keratin proteins are most attractive part for skin care applications due to its characteristics like hydrophilic and film forming. A coating or film on the skin is formed by keratin molecule which provide smooth and soft sensation.

\section{Uses as fertilizers}

Plant metabolizing enhancer organic fertilizers was prepared by using sulfur bound amino acid solution (Chikura et al. 1994). The composting of chicken feather was also used to produce biofertilizers (Ichida et al. 2001; Kornillowicz-Kowalska and Bohacz 2010). Keratin is a good nitrogen source used to prepare the fertilizers (Reddy 2015). Bacteria and fungi produces keratinolytic enzymes which help to degrade the waste biomass of Keratin. Both keratinolytic bacteria and fungi are proposed for use in composting. Among bacteria Bacillus genus produces plenty of keratinolytic enzymes and actinomycetes also contribute to keratin degradation ( Letourneau et al. 1998; Lin et al. 1999; Ichida et al. 2001; Tiquia 2005; Tiquia et al. 2005). High amounts of nitrogen in feathers makes them excellent to be used as fertilizers but the presence of cystine linkages, makes it difficult to degrade, so it made feather biomass less interesting to be used as a fertilizers (Hadas and Kautsky 1994; Gurav and Jadhav 2013). Some studies have been carried out to increase the utility of waste feather as biofertilizer. In a previous study, the release of nitrogen was increased by treatment of feather with Chryseobacterium spp. These hydrolyzed feathers fertilizers were used for banana plants and can be applicable as root dose and shoot dose for other cultivation crops (Gurav and Jadhav 2013). Feather waste treated with thermophilic actinomycetes strain was also used as a fertilizer for rye grass cultivation (Gousterova et al. 2012).

\section{Keratins in biomedical applications}

Cell adhesion sequences which normally present in fibronectin and cellular binding motifs present in keratin used as sites for cellular attachment (Feughelman and Robinson 1971; Marshall et al. 1991) This feature made keratin an ideal material for the synthesis of biomaterial in medical applications. Natural proteins considered healthy for skin and hair because of their hydrophilic nature. The monomeric units of natural keratin can be able to penetrate in the skin and hair cuticle and able to nourish without any side effects. It is also used as a wound healing agent because oxidization of keratinous materials cleaves and oxidizes some of the disulfide linkages to form water soluble peptides. The solid base for research in keratin directed to the growth of many biomaterials which are keratin-based for use in biomedical applications (Rouse and Van Dyke 2010). Keratin extracted from wool and human hair used to prepare the protein films, which was used to discover the structural and biological properties of self-assembled keratins from number of years. Dissolved feather keratin can be used to develop protein fibers and 2D and 3D scaffolds, which can be used for tissue engineering (Xu et al. 2014b). The property of extracted keratin proteins to self-congregate and polymerize into complex 3D structures has led to their work as scaffolds for tissue engineering (Rouse and Van Dyke 2010) and fabricated keratin based composite nanofiber by electro spinning used as a application in tissue engineering and regenerative medicines (Edwards et al. 2014; Boakye et al. 2015) . Similarly, in another study, chicken feather extracted keratin for the formation of fabricated keratin films were used in controlled drug delivery systems (Poole et al. 2009; Yin et al. 2013). Generally protein fibers are preferred over cellulose and other synthetic fibers due to the unique property. Many attempts have been made to produce regenerated protein fibers from plants and animals. Feather keratin is one of the potential source for regenerated fiber. Keratin extracted from feathers and developed regenerated fibers similar to sheep wool (Xu et al. 2014b). Because of the presence of high crosslinking by cystine formulation of micro and nano particle from feather is difficult, but some researcher prepared micro and nanoparticles successfully from feather keratin. Keratin was converted into useful microparticle by treatment with ionic liquid, 1butyl-3-methylimidazoliumchloride (Sun et al. 2009). Treated feathers have low surface area but having higher ion sorption capacity than untreated feathers due to their hydrophilic nature. $\mathrm{Xu}$ et al. (2014b) developed nanoparticle (50-130 nm) from feather keratin which showed good biocompatibility and stability essential for controlled drug release. These particle can approach to various organs 
of mice but maximally found in kidney then liver and followed by spleen. These keratin particles were water stable unlike other nanoparticle and there is no need for any crosslinking or other chemical modification thus suitable for medical application. These properties enhanced the utility of keratin based nanoparticles in biomedical use. These also showed affinity towards other biomolecules e.g. Graphene oxide and its derivative have potential application in biomaterials. (Amieva et al. 2014) used feather keratin to check the interaction of these molecules with that of graphitic layers. The result showed that the grafting by keratin enhance the attachment of Escherichia coli cells on graphitic films. Poole et al. (2011) develop films by using feathers keratin which was dissolved by using $\mathrm{Na}_{2} \mathrm{~S}$. Yield of feathers after different time of hydrolysis was studied using different concentrations of $\mathrm{Na}_{2} \mathrm{~S}$. Keratin have molecular weight of $20 \mathrm{KDa}$ extracted from chicken feather which was used to form films for controlled drug release applications(Yin et al. 2013). Film formed have good mechanical properties due to large amount of cystine linkage. Recently, human hair keratin was used for keratin-based biomaterials, which have been utilized for tissue regeneration ( Lee 2014) and humanhair keratin to enrich human mesenchymal stem cells for clinical applications (Hartrianti et al. 2015).

\section{Keratin in feedstock}

Feather hydrolysate obtained by chemicalthermal hydrolysis of chicken feather is rich in amino acids and polypeptides(Coward-Kelly et al. 2006). Due to similar composition with soybean protein and cotton seed protein the hydrolysate used as diet supplement for feeding ruminants. Enzymatic-alkaline hydrolysis of feather keratin for feed was done by (Dalev 1994; Dalev et al. 1996). Enzymatic modification through enrichment with lysine leads to increase in the feed nutritive value (Dalev et al. 1997) Raw horns and hoofs are put on high pressure in a rendering plant to make horn meal. Keratin is a useful protein which is helpful to prepare the animal feed (Brandelli et al. 2015).

\section{Keratin in environmental remediation}

The hollow structure and alpha helix is present in feathers for building uniform micro porous material having high surface area were used as electrode material which is environment friendly (Zhan and Wool 2011). Poole et al. in 2009 stated that the fibers obtained from keratin were environmental friendly, renewable and biodegradable. Development of keratin-based material has the potential for revolutionizing the bio-based green materials' world due to their biodegradability, biocompatibility, natural abundance and mechanical durability (Poole et al. 2009; Balaji et al. 2012). Strength and modulus of the single feather is up to $300 \mathrm{MPa}$ and $6 \mathrm{GPa}$ which is better than most of wool fibers ( $\mathrm{Li}$ and Wang 2013). Feathers can be used to made thermoplastic films for packaging of food and other applications. But the feathers are non-thermoplastic, so many chemical modifications are required to make them thermoplastic. (Reddy et al. 2013) reported the synthesis of thermoplastic by alkaline hydrolysis of feather. To make stable feather film, synthetic monomer can be added to feathers. Grafting of feather by acrylic monomers (methyl acrylate, methyl methacrylate and butyl acrylate) was also employed to improve the properties of feathers based thermoplastic (Jin et al. 2011). Other processes like acetylation and etherification were also used to develop other commercial products of feathers (Hu et al. 2011; Reddy et al. 2013; Shi et al. 2014). Feather degradation done by using microorganisms is cost effective and ecologically safe form of the continuously accumulated waste management (Grazziotin et al. 2006; Syed et al. 2009; Vasileva-Tonkova et al. 2009).

\section{Uses in leather and textile processing}

Keratin wastes can also be used in leather tanning processes. Keratin hydrolysate is used in filling cum retaining operation in leather processing (Sastry et al. 1986; Sehgal et al. 1987; Karthikeyan et al. 2007). Hand spun yans can be made by blending feathers fibers (barbs) with cotton (Reddy and Yang 2007). Yarn sizing agent is a protective layer added on to the surface of yarns to improve weaving performance. Feathers can serve as a yarn sizing agent for textile yarns (Yang and Reddy 2013; Reddy et al. 2014a; Reddy et al. 2014b). It helps to improve the tensile strength and abrasion resistance of the yarns. Polyvinyl alcohol is used for textile sizing but is 
expensive and difficult to degrade, so feather can be a good alternative to replace it.

Table 1- Applications of keratin from different sources

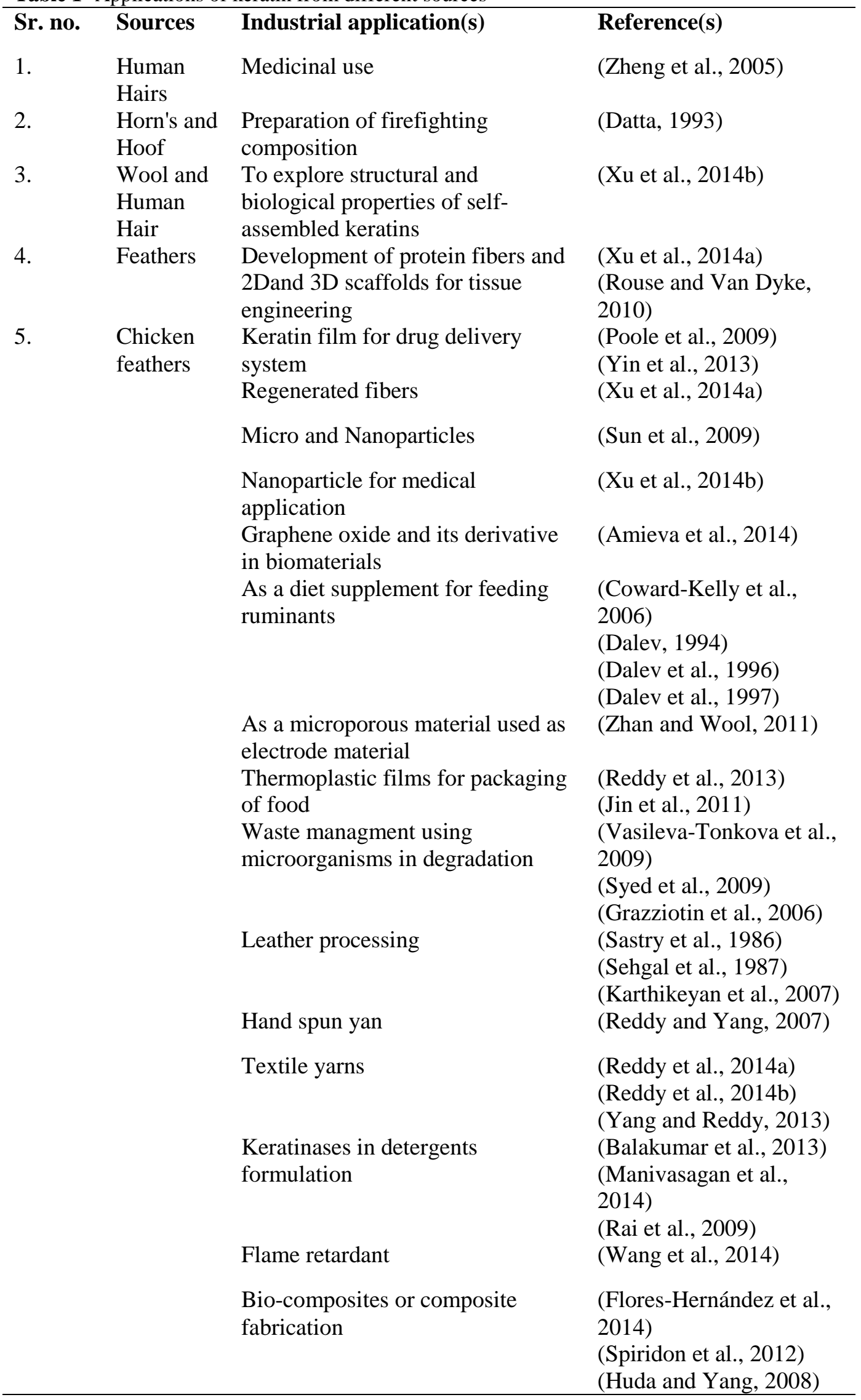


(Huda and Yang, 2009)

Biofertilizer

(Ichida et al., 2001)

(Kornillowicz-Kowalska

and Bohacz, 2010)

(Gurav and Jadhav, 2013)

(Hadas and Kautsky,

1994)

(Gousterova et al., 2012)

The enzyme keratinases can be used as a fertilizer for de-hairing in leather industry, detergent, feed and other biomedical products. Keratinase can be isolated and purified from poultry feathers (Balakumar et al. 2013). It was produced by treating feathers with ammonium chloride, sodium chloride, and potassium phosphate. Actinobacterium actinoalloteichus MA-32 has also been reported to produce keratinase which was used in detergent formulation (Manivasagan et al. 2014). It is worthy to note that the detergent containing keratinase have good removal power of the blood, paint and dye stains from fabrics. (Rai et al. 2009) reported that Bacillus subtilis strain RM-01 was used to generate feathers keratinase having molecular weight $20.1 \mathrm{kDa}$. He reported maltose and sodium nitrate were the co carbon and co-nitrogen sources. The keratinase produced was suitable as an additive for laundry detergents (Rai et al. 2009) The presence of high amount of nitrogen in feathers made it a useful material as flame retardants (Wang et al. 2014). Hydrolyzed feathers were used to prepare P-N based flame retardant. A yellowish feather based flame retardant was formed which was used for cotton fabrics. High flame retardancy was imparted to the fabrics after treating with the flame retardant which was based on feathers (Wang et al. 2014). Some biocomposites were developed from feathers which were used as reinforcement and as a matrix. Completely degradable biocomposites were formed with the use of chitosan-starch as matrix and feather component as reinforcement. In a recent study a film was prepared by pouring the above mixture into glass plate which was then evaporated (FloresHernández et al. 2014). (Spiridon et al. 2012) mixed feather fibers with low density polyethylene in an extruder and form thin composite sheets. Change in the concentration of feather has unchangeable effect on impact strength but modulus barrier properties of the film also improved. Huda and Yang (2008; 2009) developed a new technique of composite fabrication in which feather fibers were put between non-woven mats which have composition of high density polyethylene or polypropylene sheath or core fibers. The reinforcing fiber and matrix were mixed and compressed to form composites.

\section{CONCLUSION}

Till date the literature survey revealed that keratin is an important component for the production of a number of value added products. The large amount of waste biomass produced by food industries as well as from animals can be utilized as substrate / raw material for the synthesis of keratin at industrial scale. The management of keratin based waste biomass by reconversion into commercially used product, will not only save the ecosystem from large amount of sludge but will also economically boost up the pharmaceutical as well as cosmetic industry. The present need is to find the green and ecofriendly methods for the extraction of keratin biomass with the minimal usage of harmful acids and chemicals. The use of keratin biomass for the production of biofertilizers is one of the area of research, still need to be explored. The bio-fertilizers can be used as a replacement for the chemical fertilizers, responsible for changing microflora and fertility of crop land fields. Thus present review provides useful information about the sources and possibilities of industrial reconstruction of keratin based biomass and the research areas yet to be explored.

\section{REFERENCES}

Alsarra IA. Chitosan topical gel formulation in the 
management of burn wounds. Int $J$ Biol Macromol. 2009; 45:16-21.

Aluigi A, Varesano A, Montarsolo A, Vineis C, Ferrero F, Mazzuchetti G, Tonin C. Electrospinning of keratin/poly(ethylene oxide) blend nanofibers. J Appl Polym Sci. 2007;104:863-870.

Amieva EJC, Fuentes-Ramirez R, MartinezHernandez A, Millan-Chiu B, Lopez-Marin L M, Castaño V, Velasco-Santos C, 2014. Graphene oxide and reduced graphene oxide modification with polypeptide chains from chicken feather keratin. Journal of Alloys and Compounds.

Arai KM, Takahashi R, Yokote Y, Akahane K. Amino acid sequence of feather keratin from fowl. European Journal of Biochemistry. 1983; 132:506-507.

Balaji S, Kumar R, Sripriya R, Rao U, Mandal A, Kakkar P, Reddy PN, Sehgal PK. Characterization of keratin-collagen 3D scaffold for biomedical applications. Polym Advan Technol. 2012;23:500-507.

Balakumar S, Mahesh N, Arunkumar M, Sivakumar R, Hemambujavalli V. Optimization of Keratinase Production by Keratinolytic Organisms under Submerged Fermentation. Optimization 2013; 5:1294-1300.

Barone JR, Schmidt WF. Effect of formic acid exposure on keratin fiber derived from poultry feather biomass. Bioresource Technol. 2006;97:233-242.

Boakye MAD, Rijal NP, Adhikari U, Bhattarai N. Fabrication and characterization of electrospun PCL-MgO- Keratin based composite nanofibers for biomedical applications. Materials. 2015; 8:4080-4095.

Brandelli A, Sala L, Kalil SJ. Microbial enzymes for bioconversion of poultry waste into addedvalue products. Food Res Int. 2015;73:3-12.

Cardamone JM. Investigating the microstructure of keratin extracted from wool: Peptide sequence (MALDI-TOF/TOF) and protein conformation (FTIR). J Mol Struct. 2010;969:97-105.

Cavello IA, Cavalitto SF, Hours RA. Biodegradation of a Keratin Waste and the Concomitant Production of Detergent Stable Serine Proteases from Paecilomyces lilacinus. Appl Biochem Biotech. 2012;167:945-958.

Chaudhari PN, Chincholkar SB, Chaudhari BL. Biodegradation of feather keratin with a PEGylated protease of Chryseobacterium gleum. Process Biochem. 2013; 48:1952-1963.

Chikura T, Izumi N, Matsumoto S. 1994. Manufacture of amino acid containing fertilizers. Jpn Kokai Tokkyo Koho JP 0640.

Coward-Kelly G, Agbogbo FK, Holtzapple MT. Lime treatment of keratinous materials for the generation of highly digestible animal feed: 2 . Animal hair. Bioresource Technol. 2006; 97:1344-1352.
Cranston R, Davis M, Scroggie J, 1986. Development of the Sirolime unhairing process. The Journal of the American Leather Chemists Association (USA).

Dalev P, Ivanov I, Liubomirova A. Enzymic modification of feather keratin hydrolysates with lysine aimed at increasing the biological value. Journal of the Science of Food and Agriculture 1997;73:242-244.

Dalev P, Ljubomirova A, Simeonova L, Ivanov I. Protein hydrolysates from waste feathers for feed and their enrichment with lysine trough enzyme catalyzed covalent binding. MEDEDELINGEN-FACULTEIT

LANDBOUWKUNDIGE EN TOEGEPASTE BIOLOGISCHE WETENSCHAPPEN 1996; 61:1641-1644.

Dalev PG. Utilisation of waste feathers from poultry slaughter for production of a protein concentrate. Bioresource Technol. 1994; 48:265-267.

Datta M. Role of keratin in fire fighting. $J$ Ind Leath Technol Assoc. 1994;43:297-299.

Douglas J, Mittal C, Thomason J, Jofriet J. The modulus of elasticity of equine hoof wall: implications for the mechanical function of the hoof. The Journal of Experimental Biology. 1996;199:1829-1836.

Edwards A, Jarvis D, Hopkins T, Pixley S, Bhattarai N. Poly( $\varepsilon$-caprolactone) /keratinbased composite nanofibers for biomedical applications. $J$ Biomed Mater $\operatorname{Res} B$ Appl Biomater. 2015;103B:21-30.

Endo R, Kamei K, Iida I, Kawahara Y. Dimensional stability of waterlogged wood treated with hydrolyzed feather keratin. Journal of Archaeological Science. 2008;.35:1240-1246.

Eslahi N, Dadashian F, Nejad NH. An Investigation on Keratin Extraction from Wool and Feather Waste by Enzymatic Hydrolysis. Prep Biochem Biotech. 2013;43:624-648.

Fang Z, Zhang J, Liu BH, Du GC, Chen J. Biodegradation of wool waste and keratinase production in scale-up fermenter with different strategies by Stenotrophomonas maltophilia BBE11-1. Bioresource Technol. 2013;140:286291.

Feughelman M, Robinson M. Some mechanical properties of wool fibers in the" Hookean" region from zero to $100 \%$ relative humidity. Textile Research Journal. 1971;41:469-474.

Flores-Hernández CG, Colín-Cruz A, VelascoSantos C, Castaño VM, Rivera-Armenta JL, Almendarez-Camarillo A, et al. 2014. All green composites from fully renewable biopolymers: Chitosan-starch reinforced with keratin from feathers. Polymers. 2014; 6:686-705.

Fraser R, MacRae T, Rogers GE. 1972. Keratins: their composition, structure, and biosynthesis. Charles C. Thomas.

Fraser RDB, Parry DAD. Macrofibril assembly in 
trichocyte (hard alpha-) keratins. J Struct Biol. 2003;142:319-325.

Gerber P, OpioC, Steinfeld H. 2007. Poultry production and the environment $-\mathrm{a}$ review. FAO publishing Web. http://www. fao. org/ag/againfo/home/events/bangkok2007/docs/ part2/2_2.pdf.

Gessesse A, Hatti-Kaul R, Gashe BA, Mattiasson B. Novel alkaline proteases from alkaliphilic bacteria grown on chicken feather. Enzyme Microb Tech. 2003; 32:519-524.

Gousterova A, Nustorova M, Paskaleva D, Naydenov M, Neshev G, Vasileva-Tonkova E. Assessment of feather hydrolysate from thermophilic actinomycetes for soil amendment and biological control application. International Journal of Environmental Research. 2012.6:467-474.

Grazziotin A, Pimentel FA, de Jong EV, Brandelli A. Nutritional improvement of feather protein by treatment with microbial keratinase. Anim Feed Sci Tech. 2006; 126:135-144.

Guhados G, Wan WK, Hutter JL. Measurement of the elastic modulus of single bacterial cellulose fibers using atomic force microscopy. Langmuir. 2005;21:6642-6646.

Gupta A, Kamarudin NB, Kee CYG, Yunus R BM, 2012. Extraction of keratin protein from chicken feather.

Gurav RG, Jadhav JP. A novel source of biofertilizer from feather biomass for banana cultivation. Environ Sci Pollut $R$. 2013;.20:4532-4539.

Hadas A, Kautsky L. Feather meal, a semi-slowrelease nitrogen fertilizer for organic farming. Fertilizer Research. 1994.;8:165-170.

Hartrianti P, Ling L, Goh LMM, Ow KSA, Samsonray R , Sow WT, et al. 2015. Modulating mesenchymal stem cell behavior using human hair keratin-coated surfaces. Stem Cells Int 2015, Article ID 752424, 9 pages doi:10.1155/2015/752424

Hill P, Brantley H, Van Dyke M. Some properties of keratin biomaterials: Kerateines. Biomaterials. 2010; 31:585-593.

Hu CY, Reddy N, Yan KL, Yang YQ. Acetylation of Chicken Feathers for Thermoplastic Applications. J Agr Food Chem. 2011; 59:10517-10523.

Huda S, Yang YQ. Composites from ground chicken quill and polypropylene. Compos Sci Technol. 2008; 68:790-798.

Huda S, Yang YQ. Feather Fiber Reinforced LightWeight Composites with Good Acoustic Properties. J Polym Environ. 2009; 17:131-142.

Ichida JM, Krizova L, LeFevre CA, Keener HM, Elwell DL, Burtt EH. Bacterial inoculum enhances keratin degradation and biofilm formation in poultry compost. J Microbiol Meth. 2001; 47:199-208.
Innoe T. 1992. Hair cosmetic for protection of skins. Eur Pat Appl, EP 469.

Jeong JH, Lee OM, Jeon YD, Kim JD, Lee NR, Lee CY, etal. Production of keratinolytic enzyme by a newly isolated feather-degrading Stenotrophomonas maltophilia that produces plant growth-promoting activity. Process Biochem. 2010; 45:1738-1745.

Ji Y, Chen J, Lv J, Li Z, Xing L, Ding S. Extraction of keratin with ionic liquids from poultry feather. Separation and Purification Technology. 2014; 132:577-583.

Jin E, Reddy N, Zhu Z, Yang Y. Graft polymerization of native chicken feathers for thermoplastic applications. J Agr Food Chem. 2011;59:1729-1738.

Jones LN. Hair structure anatomy and comparative anatomy. Clin Dermatol. 2001;19:95-103.

Kakkar P, Madhan B, Shanmugam G. Extraction and characterization of keratin from bovine hoof: A potential material for biomedical applications. Springer Plus. 2014; 3:596.

Kaplin I, Schwan A, Zahn H. Effects of cosmetic treatments on the ultrastructure of hair. Cosmet Toiletries. 1982;97:22-26.

Karthikeyan R, Balaji S, Sehgal P. Industrial applications of keratins-a review. Journal of Scientific and Industrial Research. 2007;66:710.

Khosa M, Ullah A. A sustainable role of keratin biopolymer in green chemistry: a review. $J$ Food Processing \& Beverages. 2013; 1:8.

Khosa MA, Wu JP, Ullah A. Chemical modification, characterization, and application of chicken feathers as novel biosorbents. Rsc Adv. 2013;3:20800-20810.

Kim JD. Purification and characterization of a keratinase from a feather-degrading fungus, Aspergillus flavus Strain K-03. Mycobiology 2007;35:219-225.

Kim, WW, Kendall, SL, 1990. Additive for hair treatment compositions. Google Patents.

Kornillowicz-Kowalska T, Bohacz J. Dynamics of growth and succession of bacterial and fungal communities during composting of feather waste. Bioresource Technol. 2010; 101:12681276.

Korol J. Polyethylene Matrix Composites Reinforced with Keratin Fibers Obtained from Waste Chicken Feathers. J Biobased Mater Bio. 2012; 6:355-360.

Kunert J. Physiology of keratinophilic fungi. Revista Iberoamericana de Micologia 2000;1:77-85.

Lee L, Baden H. Chemistry and composition of the keratins. International Journal of Dermatology. 1975; 14:161-171.

Lee H, Noh K, Lee SC, Kwon IK, Han DW, LeeI S, et al. 2014. Human hair keratin and its-based biomaterials for biomedical 
applications. Tissue Eng Regen Med. 2014;1(4): 255-265.

Letourneau F, Soussotte V, Bressollier P, Branland P, Verneuil B. Keratinolytic activity of Streptomyces sp. S. K1-02: a new isolated strain. Letters in Applied Microbiology. 1998;26:77-80.

Li R, Wang D. Preparation of regenerated wool keratin films from wool keratin-ionic liquid solutions. J Appl Polym Sci. 2013; P 127:26482653.

Lin X, Inglis G, Yanke L, Cheng K. Selection and characterization of feather-degrading bacteria from canola meal compost. Journal of Industrial Microbiology and Biotechnology. 1999; 23:149-153.

Manivasagan P, Sivakumar K, Gnanam S, Venkatesan J, Kim SK. Production, Biochemical Characterization and Detergents Application of Keratinase from the Marine Actinobacterium Actinoalloteichus sp. MA-32. Journal of Surfactants and Detergents. 2014; 17:669-682.

Marchisio VF. Keratinophilic fungi: their role in nature and degradation of keratinic substrates. Biology of Dermatophytes and Other Keratinophilic Fungi. 2000;86-92.

Marsal A, Cot J, Bartoli E, Bosch T, Manich A. Oxidising unhairing process with hair recovery. J Soc Leath Tech Ch. 2002; 86:30-33.

Marshall R, Orwin DG, Gillespie J. Structure and biochemistry of mammalian hard keratin. Electron Microscopy Reviews. 1991;4:47-83.

Moore GR, Martelli SM, Gandolfo C, Sobral PJA, Laurindo JB. Influence of the glycerol concentration on some physical properties of feather keratin films. Food Hydrocolloid. 2006;20:975-982.

Natarajan V, Saravanakumar P, Madhan B. Collagen adsorption on quercetin loaded polycaprolactone microspheres: Approach for "stealth" implant. Int J Biol Macromol. 2012;50:1091-1094.

Onifade A, Al-Sane N, Al-Musallam A, AlZarban S. A review: potentials for biotechnological applications of keratindegrading microorganisms and their enzymes for nutritional improvement of feathers and other keratins as livestock feed resources. Bioresource Technol. 1998;66:1-11.

Park M, Kim BS, Shin HK, Park SJ, Kim HY. Preparation and characterization of keratinbased biocomposite hydrogels prepared by electron beam irradiation. Mat Sci Eng C-Mater. 2013; 33:5051-5057.

Poole AJ, Church JS, Huson MG. Environmentally Sustainable Fibers from Regenerated Protein. Biomacromolecules. 2009;10:1-8.

Poole AJ, Lyons RE, Church JS. Dissolving feather keratin using sodium sulfide for bio-polymer applications. J Polym Environ. 2011;19:995-
1004.

Rai SK, Konwarh R, Mukherjee AK. Purification, characterization and biotechnological application of an alkaline $\beta$-keratinase produced by Bacillus subtilis RM-01 in solid-state fermentation using chicken-feather as substrate. Biochemical Engineering Journal. 2009; 45:218-225.

Ramadass SK, Perumal S, Jabaris SL, Madhan B. Preparation and evaluation of mesalamine collagen in situ rectal gel: A novel therapeutic approach for treating ulcerative colitis. Eur $J$ Pharm Sci. 2013;48:104-110.

Ramasami T, Prasad B. Environmental aspects of leather processing. Proceedings of the LEXPOXV, Calcutta, 1991; India:43.

Ramshaw JAM, Peng YY, Glattauer V, Werkmeister JA. Collagens as biomaterials. $J$ Mater Sci-Mater M. 2009;20:3-8.

Reddy N. Non-food industrial applications of poultry feathers. Waste Manage. 2015; 45: 91107.

Reddy N, Chen L, Zhang Y, Yang Y. Reducing environmental pollution of the textile industry using keratin as alternative sizing agent to poly (vinyl alcohol). Journal of Cleaner Production. 2014a; 65:561-567.

Reddy N, Jiang QR, Jin EQ, Shi Z, Hou XL, Yang YQ. Bio-thermoplastics from grafted chicken feathers for potential biomedical applications. Colloid Surface B. 2013;110:51-58.

Reddy N, Shi Z, Temme L, Xu H, Xu L, Hou X, et al. Development and characterization of thermoplastic films from sorghum distillers dried grains grafted with various methacrylates. J Agr Food Chem. 2014b;62:2406-2411.

Reddy N, Yang YQ. Structure and properties of chicken feather barbs as natural protein fibers. $J$ Polym Environ. 2007;15:81-87.

Reichl S, Borrelli M, Geerling G. Keratin films for ocular surface reconstruction. Biomaterials. 2011;32:3375-3386.

Rizvi TZ, Khan MA. Temperature-dependent dielectric properties of slightly hydrated horn keratin. Int J Biol Macromol. 2008;42:292-297.

Rouse JG, Van Dyke ME. A Review of KeratinBased Biomaterials for Biomedical Applications. Materials. 2010;3:999-1014.

Sangali S, Brandelli A. Isolation and characterization of a novel feather-degrading bacterial strain. Appl Biochem Biotech. 2000;87:17-24.

Sastry T, Sehgal P, Gupta K, Kumar M. Solubilised keratins as a filler in the retanning of upper leathers. Leather Sci. 1986; 33:345.

Schrooyen PMM, Dijkstra PJ, Oberthur RC, Bantjes A, Feijen J. Stabilization of solutions of feather keratins by sodium dodecyl sulfate. $J$ Colloid Interf Sci. 2001;240:30-39.

Sehgal P, Sastry T, Kumar M. Effect of keratin filler in retanning of nappa garment leathers. 
Leather Sci. 1987;34.

Shi Z, Reddy N, Hou XL, Yang YQ. Tensile Properties of Thermoplastic Feather Films Grafted with Different Methacrylates. Acs Sustain Chem Eng. 2014; 2:1849-1856.

Sionkowska A. The potential of polymers from natural sources as components of the blends for biomedical and cosmetic applications. Pure Appl Chem. 2015; 87(11-12):1075-1084.

Spiridon I, Paduraru OM, Rudowski M, Kozlowski M, Darie RN. Assessment of Changes Due to Accelerated Weathering of Low-Density Polyethylene/Feather Composites. Ind Eng Chem Res. 2012;51:7279-7286.

Srinivasan B, Kumar R, Shanmugam K, Sivagnam UT, Reddy NP, Sehgal PK. Porous Keratin Scaffold-Promising Biomaterial for Tissue Engineering and Drug Delivery. J Biomed Mater Res B. 2010; 92B:5-12.

Sun P, Liu ZT, Liu ZW. Particles from bird feather: A novel application of an ionic liquid and waste resource. J Hazard Mater. 2009; 170:786-790.

Syed DG, Lee JC, Li WJ, Kim CJ, Agasar D. Production, characterization and application of keratinase from Streptomyces gulbargensis. Bioresource Technol. 2009;100:1868-1871.

Taylor M, Bailey D, Feairheller S. 1987. A review of the uses of enzymes in the tannery. The Journal of the American Leather Chemists Association (USA).

Teresa KK, Justyna B. Biodegradation of keratin waste: Theory and practical aspects. Waste Manage. 2011; 31:1689-1701.

Thanikaivelan P, Rao JR, Nair BU, Ramasami T. Zero discharge tanning: A shift from chemical to biocatalytic leather processing. Environ Sci Technol. 2002;36:4187-4194.

Tiquia SM. Microbiological parameters as indicators of compost maturity. $J$ Appl Microbiol. 2005;99:816-828.

Tiquia SM, Ichida JM, Keener HM, Elwell DL, Burtt EH, Michel FC. Bacterial community profiles on feathers during composting as determined by terminal restriction fragment length polymorphism analysis of $16 \mathrm{~S}$ rDNA genes. Appl Microbiol Biot. 2005;67:412-419.

Tombolato L, Novitskaya EE, Chen PY, Sheppard FA, McKittrick J. Microstructure, elastic properties and deformation mechanisms of horn keratin. Acta Biomaterialia. 2010; 6:319-330.

Ullah A, Vasanthan T, Bressler D, Elias AL, Wu JP. Bioplastics from Feather Quill. Biomacromolecules. 2011;12:3826-3832.

Vasconcelos A, Freddi G, Cavaco-Paulo A. Biodegradable materials based on silk fibroin and keratin. Biomacromolecules. 2008; 9:12991305.

Vasileva-Tonkova E, Gousterova A, Neshev G. Ecologically safe method for improved feather wastes biodegradation. Int Biodeter Biodegr.
2009; 63:1008-1012.

Velasco MVR, Dias TCD, de Freitas AZ, Vieira N D, Pinto CASD, Kaneko TM, Baby AR. Hair fiber characteristics and methods to evaluate hair physical and mechanical properties. Braz $J$ Pharm Sci. 2009;45:153-162.

Verheyen, L, Wiersema, D, Hulshoff-Pol, L, Brandjes, P, Westra, P, Bos, J, Jansen, J, 1996. Management of waste from animal product processing. Livestock and Environment, finding a balance. Internal Agriculture centre, Wageningen, the Netherlands.

Wagner RDC, Joekes I. Hair protein removal by sodium dodecyl sulfate. Colloid Surface $B$. 2005;41:7-14.

Wang XY, Lu CQ, Chen CX. Effect of ChickenFeather Protein-Based Flame Retardant on Flame Retarding Performance of Cotton Fabric. J Appl Polym Sci. 2014;131.

Wang YX, Cao XJ. Extracting keratin from chicken feathers by using a hydrophobic ionic liquid. Process Biochem. 2012;47:896-899.

Weigmann H, Kamath Y, Ruetsch S. Characterization ofsurface deposits on human hair fibers. J Soc Cosmet Chem. 1990;41:379390.

Wojciechowska E, Włochowicz A, WesełuchaBirczyńska A. Application of Fourier-transform infrared and Raman spectroscopy to study degradation of the wool fiber keratin. $\mathrm{J} \mathrm{Mol}$ Struct. 1999;511:307-318.

Xu H, Cai S, Xu L, Yang Y. Water-stable threedimensional ultrafine fibrous scaffolds from keratin for cartilage tissue engineering. Langmuir. 2014a;30:8461-8470.

Xu H, Shi Z, Reddy N, Yang Y. Intrinsically WaterStable Keratin Nanoparticles and Their in Vivo Biodistribution for Targeted Delivery. J Agr Food Chem. 2014b;62:9145-9150.

Yamauchi K, Maniwa M, Mori T. Cultivation of fibroblast cells on keratin-coated substrata. Journal of Biomaterials Science, Polymer Edition. 1998;9:259-270.

Yamini Satyawali, S S, 2013. Enzymatic Electrosynthesis: An Overview on the Progress in Enzyme- Electrodes for the Production of Electricity, Fuels and Chemicals. Journal of Microbial \& Biochemical Technology.

Yang YQ, Reddy N. Potential of using plant proteins and chicken feathers for cotton warp sizing. Cellulose. 2013;20:2163-2174.

Yin XC, Li FY, He YF, Wang Y, Wang RM. Study on effective extraction of chicken feather keratins and their films for controlling drug release. Biomater Sci-Uk. 2013;1:528-536.

Zhan M, Wool RP. Mechanical properties of chicken feather fibers. Polymer Composites. 2011;32:937-944.

Zheng Y, Du X, Wang W, Boucher M, Parimoo S, Stenn K. Organogenesis from dissociated cells: 
Gupta, A et al.

generation of mature cycling hair follicles from skin-derived cells. Journal of Investigative Dermatology. 2005;124:867-876.

Zoccola M, Aluigi A, Tonin C. Characterisation of keratin biomass from butchery and wool industry wastes. J Mol Struct. 2009; 938:35-40.

Received: 06 November 2015 Accepted: 07 March 2016 